\title{
Student Achievement and Government Intervention: What to Learn from Teresina, Piauí, Brazil
}

\author{
Kléber Montezuma Fagundes dos Santos \\ State University of Piauí, Brazil \\ Guiomar de Oliveira Passos \\ Federal University of Piauí, Brazil.
}

Doi: 10.19044/esj.2018.v14n10p252 URL:http://dx.doi.org/10.19044/esj.2018.v14n10p252

\begin{abstract}
This text analyzes interventions by the Teresina municipal government to influence student performance, making test score results fall among the best of the Brazilian state capitals on assessments by the Anísio Teixeira National Institute for Educational Studies and Research (Instituto Nacional de Estudos e Pesquisas Educacionais Anísio Teixeira [INEP]) despite having the highest national proportion of the poor (27.6\%). Using bibliographic data, the authors try to identify the factors favoring this performance. It was verified that Teresina implemented continuous and articulated actions, programs and projects, adopted a result and efficiency-based management model, introduced an evaluation and valorization merit system, measured and recognized in various ways. Educational policies and practices seem to follow a previously elaborated script in which each manager appropriates the actions of their predecessors, giving them continuity, perfecting and expanding them. In short, the public policies of each government were conditioned by preceding administrations. This had as its mainstay the longevity of the municipal government managed by the same political group, responsible for most of the organizational and educational policy initiatives, for the ideas and practices that characterized the performance of the municipal administration. The objective conditions offered by the new institutional framework, expressed by the political continuity, in combination with the subjective factors constitute the best explanations for understanding why the municipality of Teresina has become "a success story".
\end{abstract}

Keywords: Effect of Municipality. Public Educational Policies. Previous policies 


\section{Introduction}

This article is part of the results from the doctoral thesis (dissertation) entitled "Teresina, the municipality where the poor learn", and analyzes the steps taken by this municipality to guarantee that its students achieve one of the best results among the Brazilian state capitals on the INEP evaluations despite its disadvantaged social and economic conditions.

Among all Brazilian state capitals, Teresina has the largest group of the poor (27.6\%). However, as Soares (2014) drew attention to, its educational results (28.3\% adequate reading abilities and $20.9 \%$ mathematics scores) compared favorably with those of Florianópolis, which has the lowest proportion of the poor $(3.4 \%)$; its students attained $24.2 \%$ in reading and $20.8 \%$ in mathematics. Even other capitals with conditions similar do Teresina, such as Fortaleza with $27.5 \%$ of the poor, obtained scores of $20.8 \%$ adequate reading competency and $12.1 \%$ in mathematics.

Question: What did the municipality of Teresina do so that its schools had one of the best performances in the country, despite its conditions of poverty? It is indeed an investigation of the "municipal effect" on school performance. This line of research about student learning, in addition to examining the characteristics of students enrolled in each school and the inschool context, has also focused on the influence of "the quality of education, infrastructural conditions, school supply and educational system management" (Soares and Alves, 2013, p. 494).

This study adds to the already existing studies about the effects of socioeconomic conditions on learning (Bourdieu, 2007), as well as the influences of schools (Alves and Soares, 2007), management policies, resource use modalities and pedagogical practices (Andrade and Soares, 2008, p. 379) on student learning achievement and the contributions of the municipal system to the results of their students, especially those of disadvantaged social origin.

The policies implemented by the Municipality of Teresina, through the Municipal Department of Education, are analyzed. Nonetheless, the policies adopted in Teresina are not compared to other municipalities, nor is there a cause-and-effect relationship between what is put in place and what is finally achieved. The case of Teresina is studied, which means that, like all research that uses this strategy, there is both the desire to understand reality in its various dimensions as well as to approach it in depth, using different data sets and evidence.

The interest was to examine what policies were implemented based upon the Federal Constitution promulgated in 1988 in order to ascertain what favored the academic results of the Municipal school system despite the population's disadvantaged social-cultural conditions. In other words, what made Teresina a municipality where the poor learn formally. Like any case 
study, any conclusions from this study are valid for the universe in question. Regarding such results, there is no guaranty as Laville and Dione (1999, p. 156) observe, "that they may apply to other cases". Even when they evidence contradicting results, these studies help understand how education systems contribute to improving learning.

To support this line of thinking, we used bibliographical research about education in Teresina and Piauí as well as other findings based upon policy mandates and educational tools; educational statistics in the state and in the city; newspapers; publications on educational actions, Pluriannual Plans, TenYear Education Plans and the most diverse number of reports. The results, presented in three parts, show actions in accordance with the conditions established by the legislation guiding the educational performance of the municipality. Thus, after the present introduction, actions undertaken before the approval of the Guiding Laws and Bases of the National Education System (Lei de Diretrizes e Bases da Educação Nacional [LDBN]) are presented in the second part. In the third part, what was implemented later is discussed. In the conclusions, the actions are analyzed, identifying factors favorable to the municipal schools' academic results notwithstanding the conditions of poverty and cultural disadvantages of its population and students.

\section{Schools in the teresina municipality before the Idbn}

The Federal Constitution made the municipalities federal units with greater participation in the national tax funds. However, the new educational regulations would only become effective eight years later with the approval of the LDBN (Law No. 9.394/1996). Until then, according to a publication by the Municipal Education Department (SEMEC [2004a]), which had been a secretariat of education since 1975, managed its school system with the autonomy allowed by existing legislations. It structured the system, organizing public tenders, conducting selection examinations for prospective teachers, approving the statute of the teaching career, democratically electing school principals, improving the infrastructure of the Secretariat and schools, enabling the qualification of teachers at both the teachers' college and higher education (college degree) levels; expanding student enrollment, and elaborating a curriculam proposal.

Of the 162 institutions of the municipal school system when the LDBN was promulgated in 1996, 68 were urban and 94 in the rural area. According to the Municipal Secretariat for Planning and General Coordination (SEMPLAN, 1996), with the direct election of Wall Ferraz as Mayor in 1986, Wait was reorganized with the election of Mayor Wall Ferraz by direct vote, urban schools increased by $278 \%, 25 \%$ in the number of rural schools and $142 \%$ in enrollment figures, from 22,000 to 53,188 students, approximately $75 \%$ in the first stage of elementary education (Teresina, 1996). Accordingly, 
the system kept to the determinations of the Ten-Year Municipal Plan of Education for All, Teresina (PDET) (Plano Municipal Decennial de Educação de Teresina para Todos), approved in 1993. As objective, the PDET was "to universalize attendance to all of school age in Teresina, offering children, youth and adults education that fulfills the elementary needs of contemporary life ".

With the introduction of the Literacy Cycle, conclusion of the curriculum and student performance evaluation of the Municipal System, the PDET took care of teaching quality. The Cycle structured elementary education in two stages. The first stage had two blocks of two years each, with a single teacher responsible for teaching and the automatic promotion from one block to the other. The second stage was divided into four annual levels, from grades 5-8, with one teacher for each area of study (SEMEC, 2004a, p.9).

The curriculum, influenced by the idea of school autonomy, consisted, according to Jose Reis Pereira, then Secretary of Education, of "methodological clues and a minimum quantity of contents" to "subsidize educational actions. It is up to all involved in the process to elaborate the Full Curriculum of the Municipal School System, in order to integrate the educational activities with the realities of the school's context" (Costa \&Vilarinho, 2005, p.5).

The institutional evaluation of the system began when the National Union of Municipal Education Officers (União Nacional de Dirigentes Municipais de Educação - UNDIME) joined the "Quality of Basic Education and Network Assessment Project", with financial support from the Ministry of Education and Culture (MEC) and the National Funds for Educational Development (Fundo Nacional de Desenvolvimento da Education - FNDE). The project was developed by the Evaluation and Educational Research Group (Núcleo de Avaliação e Pesquisa Educacional - NAPE), Federal University of Pernambuco - UFPE (Rodrigues, 2000). The project consisted of an objective test of Portuguese and Mathematics applied to 4th and 5th grade students (5th and 6th years) and a questionnaire about gender, age, formal education, inservice training and pedagogical experience given to the teachers of the classes tested (Rodrigues, 2000, p.16).

Thus, it met the conditions required by the LDBN of December 20, 1996 for receiving resources from the Funds for the Maintenance of Elementary Education and Teacher Valorization, (Fundo de Manutenção de Ensino Fundamental e Valorização do Magistério, FUNDEF), instituted through the $14^{\text {th }}$ Constitutional Amendment of September 12, 1996 and regulated by Law No. 9.424, December 24 of that same year, and by Decree No. 2.264, dated June 1997. 


\section{Teresina municipal schools after the ldbn}

The approval of the LDBN and FUNDEF gave the municipality the necessary conditions for achieving universal elementary education as well as for the improvement of management and infrastructure. For universal education the programs that most stood out were the: All-In-School Program and Teresina Scholarship Program. The first consisted of an intense campaign in all the media to locate out of school children between 7 (seven) and 14 (fourteen) years. The second also aimed to attract those who were out of school, but this time, focusing on the most vulnerable segments, requiring them to enroll as a condition for the transfer of income.

As a result, not only did enrollments increase $18 \%$, but the Municipal System now offered $35 \%$ of the local primary school vacancies, with the net primary school attendance rate rising from $83 \%$ in 1991 to $96 \%$ in 2000 , according to data from the United Nations Development Program (UNDP) (2013), indicating universalization of elementary schooling and, consequently, the inauguration of a new stage which involved improving the quality of teaching, management and infrastructure.

The improvement in teaching quality, as envisaged in the Ten-Year Plan, was anchored in initial and continuing teacher training and in actions aimed at improving the performance of primary school students in Portuguese and Mathematics. Examples of these interventions included the Olympian Mathematics Program (Programa de Olimpíadas de Matemática) and the Writing Contest (Concurso de Redação), in which participated respectively, 180 students from 106 schools and 230 students from 52 schools (Costa \& Vilarinho, 2005). The best-rated students with their teachers, won trips to the United States to get to know Disney in Orlando, Florida; others won trips to historic Brazilian cities like Ouro Preto, Tiradentes, Sabará in Minas Gerais, among others (Costa \&Vilarinho, 2005).

In the municipal administration, the highlight was the creation of a Rotation Fund, following the examples of the Money Directly to the School Program, (Programa Dinheiro Direto para Escola, PDDE), created through the FNDE Resolution, No. 12, of May 10, 1995. The Municipal Fund, instituted by Law No. 2,511 of March 16, 1997 and regulated by Decree No. 3.454, of May 7, 1997, allowed schools to receive financial resources for the acquisition of material and the realization of small services defined by community assemblies and administered by the School Board (SEMEC, 2004).

For managing the System, in addition to the creation of the Municipal Council for Monitoring and Social Control of the FUNDEF, the Municipal System of Education and adhesion to the Funds for Strengthening Schools 
Program, (Fundo de Fortalecimento da Escola, FUNDEscola) ${ }^{31}$ were highlights.

The Municipal School System of Teresina, (Sistema Municipal de Ensino de Teresina, SME) was one of the innovations brought in by the Federal Constitution of 1988 when it defined in its Art. 211, that it would be up to the Union, States, Federal District and Municipalities to organize their education systems, to define forms of collaboration, in order to ensure the universalization of compulsory education. According to the single paragraph of Art. 11 of the LDBN 1996, municipal governments could choose to institute their own education systems, within the state system or compose together, a single system for basic education. Teresina opted for the creation of its own system through Law No. 2.900, dated January 17, 2000.The municipality decided to exercise its established constitutional autonomy and, with that, being able to "lower supplementary norms for its education system" (Law No. 9.394, 1996, article 11, item III), to institute standards, procedures and curricula more appropriate to local needs and peculiarities, besides favoring relevant decision-making and greater speed regarding educational matters.

The Municipal School System of Teresina (SME), consisted of the Secretariat, as administrative unit, the Council, as a collegiate body as well as elementary and nursery schools, maintained and administered by the municipal government. The system also included early childhood educational institutions, created and maintained by private initiatives (SEMEC, 2004a, p.69).

Responsibilities of the Municipal Council of Education as defined in art. 2 of the Law, were "to elaborate complementary norms for the Municipal Education System, as well as to study, plan, advise and approve educational questions (matters) pertinent to the administrative and pedagogical functioning of the establishments that integrate it" (SEMEC 2004, p. 69). According to art. 3, the Secretariat was required to:

oversee compliance with the norms and decisions issued by the Municipal Council of Education, register and supervise the establishments that integrate the Municipal System of Education, as well as validate and register certificates or diplomas of completion of Elementary School in SME establishments (SEMEC, 2004, p. 69).

The adhesion to FUNDEscola, through a Technical and Financial Cooperation Agreement between the Municipality and the Ministry of Education (MEC) through the National Funds for the Development of Education - FNDE (2000), made it possible to study the National Curricular Guidelines and exchange experiences with the systematization of teaching

\footnotetext{
${ }^{31}$ National Funds for Educational Development Program - FNDE/MEC, with interface of the state and municipal Departments of Education of the Northern, Northeastern and WestCentral regions with financing from the World Bank (BRAZIL, 2000).
} 
strategies as well as the implementation of the Teacher Literacy Training Program, (Programa de Formação de Professores Alfabetizadores, PROFA), (SEMEC, 2002, p.4) and the School Development Plan, o (Plano de Desenvolvimento da Escola, PDE). The first plans, totally financed by the FNDE/Fundescola, were elaborated in 04 (four) schools of the system that met the criteria defined by the Program in terms of having less than 200 (two hundred) students, executing units (School Councils) and "minimum operating conditions and strong leadership " (Rocha \& Costa, 2008, p.6). "Strong leadership" was justified by the need for the school to take responsibility for directing and coordinating the development of the PDE, involving "all segments of the school and the school community, in order to improve students' performance" (Amaral, 2001, p. 17).

Public education of the municipality of Teresina, therefore, reached the twenty-first century anchored, on one hand, in its Municipal Education System and on the other, in Fundescola. The first consisted of a mechanism for the legal affirmation of its autonomy, which was in line with the foundations of the federal system, since it had its educational responsibilities established in a legal order and administrative structure and, at the same time, had defined the ways of cooperation and articulating with the other members of the federation. The second, based on the relationship with FUNDEscola pointed to the logic of strategic planning, as well as a results-based and efficiency management style.

These ideas guided the educational management of the municipality. Thus, as part of FUNDEscola, teacher qualifications continued through the Program for School Learning, (Programa da Aprendizagem Escolar, GESTAR), for teachers of Portuguese and Mathematics in the 1st and 2nd blocks of schooling, School Development benefits for 97 schools with a sum of $\mathrm{R} \$ 876,000.00$ (SEMEC, 2007a). Strategic planning was also introduced in the Secretariat (Rocha \& Costa, 2008).

The valorization of the teaching profession counted with the approval of a new Statute and the Plans for Salaries and Job Placement for Public School Teaching in the Municipal System of Teresina, (Rede de Ensino do Município de Teresina, PCCS) through Law No. 2,972 of January 17, 2001 and with the institution, through Law No. 3,089, of April 18, 2002, of the "School Performance Bonus". This Bonus consisted of a remuneration for the teaching staff (pedagogue, director, deputy director and teachers in effective classroom activity), according to the average scores of each school on the external evaluation of the system based upon the approval rates of the students, the Age-Class Distortion and School Drop-out Rates (article 1, paragraph 1). Each of these indicators had a weight whose sum totaled 100 (one hundred) percent and the scores ranked the schools, in groups that ranged from A, with 
the best performance (more than $80 \%$ ), to E, with less than 50 percentage points.

It was also at this time that the School Feeding Council, (Conselho de Alimentação Escolar, CAE) was established through Municipal Law No. 2,989, of May 14, 2001, and the Municipal Council of Education of Teresina - CME by Municipal Law No. 3,058, of December 19 of 2001. The Ten-Year Education Plan of Teresina (2003-2013) was also approved. The Plan defined as objectives, to:

- Universalize school attendance to meet the educational demands of the city, guaranteeing access to quality education, continuity and the success of all children, young people and adults, based on a perspective of Education for all.

- $\quad$ Eradicate illiteracy, aiming to include women and men from Piauí in the socioeconomic and political process of the state and the country, increasing opportunities for generating and increasing work and income, reducing poverty and recovering their dignity as citizens (SEMEC, 2003). , p. 27).

The goals to be achieved by these policies in the areas covered by the municipal education system were: to reduce the illiteracy rate to 5\%; reach in 10 years, the "primary school enrollment rate - 1st to 4th grades - of at least $90 \%$ "; assist $60 \%$ of children from zero to three years and $100 \%$ from four to six years; enrollment of all 6-year-olds into elementary school; ensure that at least $90 \%$ of children and adolescents remain for 8 years in the compulsory schooling process from 7 to 14 years of age"; reduce "by at least $80 \%$ " the age/class (grade) distortion [...]", to keep drop-out and retention (failure) rates at a maximum of $10 \%$ per year; to universalize "elementary education" for children and adolescents from 7 to 14 years (SEMEC, 2003, pp. 32-33).

The objectives of the Ten-Year Plan of Education for All (MEC, 1993; SEMEC, 1993) were achieved, especially as to the universalization of school attendance as related to educational demands, and the quality of teaching as guarantee for learning. To this end, measures were implemented to regulate school progress and literacy, with the Ayrton Senna Institute (IAS), which began to monitor progress within the system using retention and dropout rates, as well as requiring planning, monitoring, evaluation and positive outcomes in all schools. Through the Special Literacy Program for first year students of elementary school still not literate, the Instituto Alfa and Beto - IAB made it possible to keep them in the school in indicated series (classes), and introduced them to workable literacy practices (SEMEC, 2010).

As such, in 2004, the "Literacy Teacher Award" was established with the objective of giving the deserved value to literacy teachers; to develop a profile of students' learning in the literacy process; to produce diagnostic information about the acquisition of reading and writing skills during the school year and to inform decision-making about planning, teacher training 
and classroom intervention (Lustosa, 2013, p 60). In this way, student literacy level and consequently, the performance of the literacy teachers were measured through the evaluation conducted by SEMEC, rewarding those who attained "the minimum of $90 \%$ of their students with a grade equal or superior to six" (SEMEC, 2008, p.32).

About this time, the 56,390 enrollment figure registered in 2004 in the municipal school system already represented $43 \%$ of the total in Teresina's elementary schools, even though it had $25 \%$ of the establishments but benefited from political continuity in local government management. The Literacy Professor program continued, and so were the partnerships with the Alfa and Beto and Ayrton Sena Institutes. So as to strengthen school autonomy, strategic planning was introduced by FUNDEscola through the school's PDE.

The partnerships with the Alfa and Beto and Ayrton Sena Institutes with the "universalization of the Metaphonic Method of literacy in all beginning (reading and writing skills, literacy) classes" (SEMEC, 2007: 43) enabled the system, whose literacy rate was $82.51 \%$ in 2003 , to increase to 92.69\% in 2009 (SEMEC, 2010). Also counting, especially with the technologies of the Ayrton Sena Institute, through the "Se Liga" (Get Connected) and "Acelera" (Speed up) Projects, the age/class distortion index was reduced from $19.86 \%$ in 2004 to $6.30 \%$ in 2008 (SEMEC, 2010).

The school became the "central axis of the educational policy" onto which "all the efforts and actions of the agents of" the Council and the Secretariat (SEMEC, 2007, 32) converged, as FUNDEscola was already helping with the "need to strengthen their ability to function and teach" (SEMEC, 2006, page 7). For this reason, the Development Plan of 74 schools was financed with resources from the Municipal Treasury and the National Fund for Educational Development. Strategic planning was also extended through training (Rocha \& Costa, 2008, p.7-8).

The "School Performance Bonus", introduced in 2002, was replaced by the "School Performance Award", established by Law No. 3.514/2006, which maintained the previous criteria, but went on to award schools (Lustosa, 2013). In addition, in compliance with Law No. 11,738/2008 and the PDET (SEMEC, 2003), the national minimum salary for teachers and other professionals in basic public education was established.

About the same time, the municipal school system had more than a third $(35 \%)$ of its schools located within the municipality and $50 \%$ of enrollments in elementary school and early childhood education. There was also a 164\% increase in the number of schools, from 67 in 2004 to 177 in 2009, and $318 \%$ of enrollments in day-care centers, from 1,665 in 2004 to 6,952 in 2009. Similarly, pre-schools also had a growth of about $160 \%$ during the same period, going from 5,593 to 14,519 units according to SEMEC (2015). 
This growth really began in 2007, when FUNDEB was constituted by Constitutional Amendment No. 53/2006, which, in contrast to the FUNDEF that it replaced, had a broader scope, covering all basic education (kindergarten, primary and secondary schooling, as well as youth and adult education). With this, there is a " $100 \%$ of municipalization of the state's Kindergarten Nursery network and the incorporation of almost all the philanthropic and community preschools in agreement with the extinct Municipal Secretariat for Children and Adolescents, (Secretaria Municipal da Criança e Adolescente, SEMCAD) according to SEMEC, (2015, p.20). As early as $2013,96 \%$ of children aged 4 to 5 years and $34.7 \%$ of children aged 0 to 3 attended school, surpassing in both cases Brazil (81.4\% and 23.2\%), the Northeast ( 87 and 19.2\%) and Piauí (93.9 and 16.1\%), according to data from the panel "Situation of planned targets", from the website "PNE in motion" of the Ministry of Education.

The substitution in 2010 of the Brazilian Social Democratic Party (PSDB), in the municipal government since 1993, by the Brazilian Labor Party (PTB) resulted in changes in educational policies. The School Performance Award, which was created in 2006, was replaced through Law No. 4,019 of 2010, by the School Team Award - 100\%, which, according to Lustosa (2013, p.60), awarded "all school staff professionals" (director, deputy director, teachers, pedagogues, secretaries, secretarial assistants, custodians, lunch attendants, concierge agents, those in activity or not, and trainees) cash amounts established by Decree 10.671 of August 23, based upon the results of the Teaching Unit from the Literacy Teacher Award or on the Basic Education Development Index, (Índice de Desenvolvimento da Educação Básica, IDEB.

Law No. 4,274, dated May 17, 2012 amended Law No. 3,513, of May 19, 2006 about the election of school principals. Under the new law, the terms, which were four (04) years, were reduced to 03 (three) years (article 5); elections take place in all schools, and those with less than six (6) classes are only allowed as candidates for director (article 3); a teacher's vote has a "weight" of $50 \%$ and that of service workers or students only $25 \%$ each. Teachers also require only a minimum of 3 years of effective teaching to be a candidate (SEMEC, 2006; 2012).

However, candidates were required to sign a Management Contract with clauses "pre-established regarding competences in administrative, pedagogical and financial management, in addition to others based upon exercising the responsibilities attached to the position". In the case of reelection, a document of the results of the performance evaluation based upon the previous Management Contract will be signed (SEMEC, 2006; 2012).

In this period, compared to 2009 , the number of elementary schools decreased by $0.7 \%$ and enrollments by 3.3\% (SEMEC, 2015). However, the Municipal Network remained with more than $50 \%$ of the enrollments in 
primary education. In pre-school education, although the number of establishments was maintained, enrollments in day-care centers were increased (from 6,952 in 2009 to 10,634), compensating for the reduction in preschool (from 14,519 to 13,504) and reflecting adjustments in the Network in order to optimize resources.

With the return of the PSDB to the municipal government in 2013, a Pluriannual Plan covering 2014-2017 entitled "A city for the people" with commitment to the quality of education was elaborated. Education was made a priority so as to improve learning and, consequently, recover the level of the Basic Education Index, lowered from 5.2 in 2011 to 5.0 in 2013 in the initial years of elementary education, and from 4.4 to 4.3 in the final years (INEP, 2015).

In order to achieve this, in 2014 the Learning Evaluation Group of the Secretariat, created in 1996, was transformed into the Educational Evaluation System of Teresina, Sistema de Avaliação de Aprendizagem de Teresina, SAETHE. Through SAETHE, SEMEC, in partnership with the Center for Public Policy and Educational Evaluation of the Federal University of Juiz de Fora (CAEd/UFJF), coordinates the execution of external evaluations like the census and transversal types for students of the municipal system in Portuguese (Reading and Writing) and Mathematics.

In addition to the evaluation system, Laws 4,499 of December 20, 2013 and 4,668 of December 22, 2014, instituted the Program for Merit Recognition within the Teresina Public Schools, primary school and early childhood education. Its purpose in the elementary school, according to art. 2 of Law 4,499 (2013), is "to motivate teaching professionals to improve teaching practice, contribute to the professionalization of teaching, as well as to raise students' academic performance". In early childhood education, according to art. 2 of Law no. 4,668 (2014), the reason is "to recognize and value collective work, considering the skills developed by the students [of] the 2nd Period of Early Childhood Education, regarding reading and writing."

The prizes, an annual bonus, are awarded to a director, deputy director, assistant director, pedagogue, teachers effectively teaching and those in teaching practice. The performance of the school on the IDEB for elementary schools, and the development and progress in reading and writing of those in early childhood as measured through External Achievement Evaluation.

In this way, the more than 80 thousand students in the 300 schools of the municipal network are systematically followed, with diagnoses that subsidize policies for continuing education and actions aimed at improving learning such as those arising from partnerships with the Alfa and Beto and Ayrton Sena Institutes. These actions also include those outside the school. Standing out among these, is the "Olympian Educational City" Program, which, according to the Annual Activity Report for 2015 (SEMEC, 2016, 
p.24), between 2013 and 2014 "benefited 150 elementary school students with high academic skills" and resulted in "more than 50 achievement medals won nationally".

This Program, though similar to the one of 1996, is also different because students prepare to compete with other public schools at the state and national levels. Thus, as many of the actions developed by the Teresina municipal education system, while the Program in question continues, it establishes a tradition and innovates at the same time.

Since becoming a federal entity, the Teresina municipality has used the prerogatives granted by the 1988 Constitution to carry out its duties as regulated by the LDBN with support first from FUNDEF, and then FUNDEB. These institutional conditions favored the universalization of elementary and pre-school education and expanded services in day-care centers. All fortified school permanency, improvement in performance, school management, and the Municipal System as a whole. The actions aimed at improved school performance included the qualification and continued professional preparation of the teachers for the systematization of their pedagogical activities. Acquisition of better reading and writing skills, teaching strategies for literacy and effective learning, especially for students with age/class distortions, and encouragement to study specific subjects like Portuguese Language and Mathematics with the promotion of several competitions among which the Knowledge Olympics stand out.

The management of the school, as 'locus of teaching and learning', had improved upon the process of choosing principals through the combination of democratic practices (direct elections and voting by the school community) and meritocratic criteria (training, qualification and a signed management contract). School councils (boards), strategic planning, transfer of funds for routine expenses, as well as those defined in the School Development Plan (PDE-Escola) and work plans approved by the school councils were instituted. An integral part included the systematic monitoring by the Secretariat and continuous performance evaluation.

Regarding the management of the System, introduced from then on, along with the constitution of the democratic instances required by the Municipal Council of Education and the Ministry of Education for the transfer of funds (Councils for FUNDEB, FUNDEF, School Feeding Program, among others), the focus was also on strategic planning, merit recognition and evaluation. Strategic planning, introduced by the FUNDEscola Program, was integrated with management to direct annual actions as well as the evaluation of results, guiding the Secretariat in the organization of management and performance evaluation. The valorization of merit was evidenced by the institution of prizes awarded to individual teachers, sometimes to all the teachers of the school, sometimes to the school team on participating in 
competitions or to the students or even the school as a whole. Evaluation, the guiding principle of school management, has been improving since the first experience, introduced even before the LDBN (1996) both in terms of the administrative structure (first as a nucleus, then as an evaluation system), and methodological and technical questions, following the innovations in the field and using the advice of institutions with proven experience.

Thus, it is perceived that what the municipality of Teresina did so that its schools would register one of the best results in the country, despite its perceived poverty, involves a set of continuously improved pedagogical and administrative actions.

\section{Conclusion}

This study examined Teresina's education, focusing on what was done since it became a federal entity according to the 1988 Constitution so that its schools would have one of the best performance results in the country, despite having more than a quarter of its population $(27.6 \%)$ made up of poor people. The path followed before the approval of the LDBN in 1996 to the present day was outlined, giving special attention to the most significant actions, their meanings, connections and results at different times during this period.

Since the Constitution of 1988, the educational activities of the Teresina City Hall, the municipality's administrative center, has benefited from the legacy of the continuity of administrative and pedagogical actions developed since the return to direct elections for mayor in the capitals in 1988 . This made it possible that the initiatives of an administrator are continued, widened, deepened and sometimes remodeled, but never abandoned by their successors. Such initiatives, under the auspices of the legal framework, were strengthened by FUNDEF's management model and the financial resources it made available. So was the universalization of elementary education and, with this, the inclusion of the quality of education in the public agenda. Also included was the establishment of mechanisms for more democratic management practices. On the one hand, the municipal administration implemented measures so that no child between the ages of 7 and 14 years would remain out of school, and took care of educational quality by dividing elementary education in two stages; one consisting of two blocks of two years and automatic promotion; and the other, with four classes (series). A new management model was also inaugurated.

To this end, it created and implemented the social control of democratic management in schools and in the System, elaborated the first TenYear Plan, established measures to ensure the autonomy of school units (pedagogical projects and curriculum defined by the school community, allocation of treasury funds), organized the network's institutional evaluation system, created the Municipal Education System and joined the FUNDEscola 
partnership. While one expressed the autonomy conferred by the Constitution; the other, the administrative model put into place, one amd the other, profoundly altering the management of municipal education in Teresina.

These innovations were not only consolidated but they left a legacy that forged the choices and, mainly created a new paradigm for managing Teresina's education system. FUNDEscola and the preparation of decennial plans were continued; as well as the system of institutional evaluation was expanded, associating it with the reward for performance and the introduction of other agencies for social control (Municipal Council of Education and School Feeding Council).

The fight against illiteracy, especially among those attending school, drop-out, retention and age/class (grade) distortion rates, were tackled through a number of strategies, and the most innovative at the time were the partnerships with non-governmental organizations such as the Ayrton Sena and the Alfa and Beto Institutes and awards for good practices both from the school and from teachers, notably from literacy teachers. As the management model took hold, especially with the search for results, the administration established quality education as the new agenda, albeit using previous initiatives such as FUNDEscola, different partnerships; awards for performance, altered in their designs and scope. Most importantly was the managerial model of administration, now, applied to the whole System.

This System, which already controlled $50 \%$ of elementary school enrollment, with the FUNDEB in 2007 and the expansion of compulsory education for children from 4 to 5 years old, also began to offer a large part of the kindergarten education that was municipalized with the incorporation of those assisted by the state as well as by philanthropic and assistance-based organizations. Besides, it emerged as a System of Quality in INEP's evaluations, presenting in the 2009 IDEB evaluations, score of 5,2 for students in the initial years, only surpassed by Palmas with 5,6, Belo Horizonte $(5,3)$ and Curitiba (5,7). For students in the final years the score of 4.7 was surpassed by Campo Grande with 4.8. In 2011, this performance was taken to task with the maintenance of 5.2 in the initial years and the reduction to 4.4 in the final years, and falls in both segments in 2013, with scores of 5.0 and 4.3, respectively.

These results coincided with the change of the governing group of the municipality which consequently, can be said to be responsible for the educational administration that designed anew, several of the already existing actions, such as awards for school performance, election of school directors and better rationalization of the system.

In fact, with the return of the PSDB political group to managing the municipality, rather than resume the same course of action as before, including preserving some changes introduced by the predecessor, such as the 
systematic election of school principals and the rationalization of school supplies, old lines of action and new procedures were broadened and intensified. Among the extended projects, were those for continuous training, the use of the educational technologies of the Alfa and Beto and Ayrton Sena Institutes, offering ways of learning outside the school context and the performance evaluation. Among the innovations, the Teresina Educational Assessment System and the institution of Merit Valorization Award Programs within the Teresina public elementary school system should be highlighted. It is true that, both are heirs of a long tradition in the Network, what we innovate is, first the scope, second, the design.

As such, factors that can be said to account for the Teresina municipal schools to have achieved some of the best results in the country, despite its poverty included continuation and articulation of actions, programs and projects, adoption of a management model based on the search for results and efficiency, as well as individual-system evaluations, merit valorization, measured and recognized in various ways. In fact, the educational actions of the municipality seem to follow a previously elaborated script in which each manager/director appropriates the actions of predecessors, giving them continuity, improving upon them, expanding them; in summary, the public policies of each government conditioned the policies of its successors.

The mainstay of this is the longevity of the municipal management by the same political group, responsible for most of the initiatives for elaborating and implementing educational policies; responsible for the ideas and practices that characterize the municipal school system and account for the performance reported. Therefore, attending to the objective conditions offered by the new institutional framework, in conjunction with the subjective elements present, expressed through continuity of a political party in power, constitute the best explanations for understanding why the schools of the municipality of Teresina have become "a success story".

\section{References:}

1. Andrade, R. J.\& Soares, J. F. (2008). O efeito da escola brasileira. Estudos em Avaliação Educacional, 19 (41), p. 379-406. DOI: http://dx.doi.org/10.18222/eae194120082067

2. Alves, M. G. \&Soares, J. F. (2007, june). Efeito-escola e estratificação escolar: o impacto da composição de turmas por nível de habilidade dos alunos. Educação em Revista, 45, p. 25-58. DOI: http://dx.doi.org/10.1590/S0102-46982007000100003

3. Amaral, J., Sob ${ }^{\circ}$. (2001).O Plano de Desenvolvimento da Escola e a gestão escolar no Brasil. Brasília: MEC/Fundescola, 2001.

4. Bourdieu, P. (2007).A escola conservadora e as desigualdades frente à escola e à cultura (A. J. Gouveia, Trad.). In: Nogueira, M. A. \&Catani, 
A. Escritos de Educação (9rd. Edition,p. 39-64). Petrópolis, RJ: Vozes.

5. Constituição da República Federativa do Brasil de 1988. (1998). Brasília. Recuperado em: 12 novembro, 2014, de http://www.planalto.gov.br/ccivil_03/constituicao/constituicao.htm.

6. Costa, M. C. R. \& Vilarinho, M. S. L. Q. (2005). Breve histórico da educação pública municipal. Teresina: Secretaria Municipal de Educação de Teresina, Piauí, Brasil.

7. Instituto Nacional de Estudos e Pesquisas Educacionais Anísio Teixeira (2015). IDEB - Resultados e Metas. Recuperado em janeiro, 2016, http://ideb.inep.gov.br/resultado/resultado/resultado.seam?cid=11332 59.

8. Instituto Nacional de Estudos e Pesquisas Educacionais Anísio Teixeira. (2015a).Plano Nacional de Educação PNE - 2014-2024: Linha de Base. Recuperado em janeiro, 2016 de http://www.publicacoes.inep.gov.br/portal/download/1362.

9. Laville, C. \& Dione, J. (1999). A construção do saber: manual de metodologia da pesquisa em ciências humanas. Porto Alegre, RS: Artmed; Belo Horizonte, MG: Editora UFMG.

10. Lei n. 9.394, de 20 de dezembro de 1996 (1996). Estabelece as Diretrizes e Basesda Educação Nacional. Recuperado em julho, 2013, de http://www.planalto.gov.br/ccivil_03/leis/19394.htm.

11. Lei $n^{\circ} 3.513$, de 19 de maio de 2006. Dispõe sobre processo de seleção de Diretores das escolas da Rede Pública Municipal de Ensino de Teresina. Recuperado em janeiro, 2016 de http://pgm.teresina.pi.gov.br/admin/upload/documentos/b287f11824. pdf.

12. Lei $n^{\circ} 4.274$, de 17 de maio de 2012. Dispõe sobre eleição de Diretores, vice-diretores ou diretores adjuntos da escolas da Prefeitura de Teresina. Recuperado em janeiro, 2016 de http://www.teresina.pi.leg.br/acervodigital/norma/lei-4274-2012.

13. Lei $n^{\circ}$ 4.499, de 20 de dezembro de 2013. Institui o "Programa de Valorização do Mérito", no âmbito das Escolas de Ensino Fundamental Regular da Rede Pública Municipal d Ensino de Teresina, na forma específica. Recuperado em janeiro, $2016 \mathrm{de}$ http://www.teresina.pi.leg.br/acervodigital/norma/lei-4499-2013.

14. Lei $n^{\circ}$ 4.668, de 22 de dezembro de 2014. Institui o "Programa de Valorização do Mérito" na Educação Infantil, no âmbito das Unidades de Ensino da Educação Infantil da Rede Pública Municipal de Ensino de Teresina. Recuperado em janeiro, 2016 de 
http://pgm.teresina.pi.gov.br/admin/upload/documentos/458ac993af.p df.

15. Lustosa, I. N. (2013).O "Prêmio Professor Alfabetizador" como política de remuneração meritocrática:o que pensam professores, gestores educacionais e dirigentes sindicais.Dissertação de mestrado Universidade Federal do Piauí, Teresina, PI, Brasil.

16. Ministério da Educação - MEC. (1993)Plano Decenal de Educação para Todos 1993-2003.Recuperado em julho, 2013 dehttp://www.dominiopublico.gov.br/download/texto/me002599.pdf.

17. Ministério da Educação. (2000). Normas para o financiamento de projetos educacionais no âmbito do FUNDESCOLA/Fundo de Fortalecimento da Escola.Recuperado em julho, 2013, de http://www.dominiopublico.gov.br/download/texto/me000569.pdf.

18. Ministério da Educação. (2006).Como elaborar o Plano de Desenvolvimento da Escola. Brasília: Autor.

19. Programa das Nações Unidas para o Desenvolvimento - PNUD. (2013).Atlas do Desenvolvimento Humano dos Municípios. Recuperado em 19 de janeiro, 2016 de http://www.atlasbrasil.org.br/2013/pt/perfil_m/teresina_pi.

20. Rocha, A. G. L. \&Costa, M. C. R (2008). Implantação do Fundescola e sua contribuição para a reestruturação das escolas à nova política [mimeo.].Secretaria Municipal de Educação de Teresina, Piauí, Brasil.

21. Rodrigues, C. M. A. (2000).Meta-avaliação da avaliação de Rede no Sistema Público Municipal de Ensino de Teresina, no ano de 1997. Trabalho deConclusão de Curso de Especialização. Universidade Federal do Piauí, Teresina, PI, Brasil.

22. Soares, J. F. (2014). Educação, Desigualdade e Pobreza. In: Eitler, K. \& Brandão, A. P (p. 57-65).Por que pobreza?: educação $e$ desigualdade. Rio de Janeiro: Fundação Roberto Marinho.

23. Soares, J. \&Alves, M. T. G. (2013, maio/agosto). Efeitos de escolas e municípios na qualidade do ensino fundamental. Cadernos de Pesquisa, 43(149), p. 492-517.DOI: http://dx.doi.org/10.1590/S010015742013000200007.

24. Secretaria Municipal de Educação. (1993).Plano Decenal de Educação para todos. Teresina: Autor.

25. Secretaria Municipal de Educação. (2002).Projeto Educação. Teresina: Autor.

26. Secretaria Municipal de Educação. (2003).Plano Decenal de Educação para Teresina-PDET, 2003. Teresina: Autor.

27. Secretaria Municipal de Educação. (2004).Legislação do Município de Teresina: a educação em destaque. Teresina: Autor. 
28. Secretaria Municipal de Educação. (2004a).A Política de educação que Teresina aprovou. Teresina: Autor.

29. Secretaria Municipal de Educação.(2007). Educação da gente de Teresina: políticas e diretrizes educacionais em prática. Teresina: Autor.

30. Secretaria Municipal de Educação. (2007a).Ensino Público Municipal: Gestão de Resultados 2003-2007. Teresina: Autor.

31. Secretaria Municipal de Educação.(2008). Diretrizes Curriculares do Município de Teresina. Teresina: Autor.

32. Secretaria Municipal de Educação. (2010).Educação em Primeiro Lugar.Teresina: Autor.

33. Secretaria Municipal de Educação (2015). Plano Municipal de Educação.Teresina: UPJ Produções.Recuperado em 03 março, 2016 de http://semec.teresina.pi.gov.br/cat_view/21-caapdet..

34. Secretaria Municipal de Educação.(2016). Relatório da gestão - 2015. Teresina: Autor.

35. Secretaria Municipal de Planejamento e Coordenação Geral SEMPLAM/PMT. (1996). Síntese das Realizações da Prefeitura Municipal de Teresina - 1993/1996. Teresina: Autor. 